\title{
A Computational Fluid Dynamics Study of Hydrogen Bubbles in an Electrochemical Reactor
}

\author{
Renata da Silva Cavalcanti ${ }^{1}$, Severino Rodrigues de Farias Neto ${ }^{1 *}$ and Eudésio Oliveira \\ Vilar $^{2}$ \\ ${ }^{1}$ Laboratório de Pesquisa em Fluidodinâmica e Imagem - LPFI; ${ }^{2}$ Laboratório de Engenharia Eletroquímica - \\ LEEQ; Departamento de Engenharia Química; Centro de Ciências e Tecnologia; Universidade Federal de \\ Campina Grande; 58109-970; Campina Grande - PB - Brasil
}

\begin{abstract}
Most electrochemical reactors present reactions with the growth and departure of gas bubbles which influence on the reactor hydrodynamics and this study is usually complex, representing a vast field for research. The present paper had as objective to study a bi-phase (gas-liquid) system aiming to foresee the influence of departure of hydrogen bubbles generated on effective electrode surface situated on cathodic semi-cell. Nevertheless, it was idealized that the gas was injected into the semi cell, through the effective electrode surface With this hypothesis, it was possible to study, and numerically analyze, the hydrodynamic behavior of the hydrogen bubbles in the interior of the study domain, applying concepts of computational fluid dynamics by using the computational applicative CFX-4 for the application of the MUSIG ("MUltiple-SIze-Group") model, taking into consideration the phenomena of coalescence and the distribution of the diameter of the bubbles.
\end{abstract}

Key words: Hydrogen, Bubble, CFD, Finite volumes, electrochemical reactor

\section{INTRODUCTION}

The numeric simulation in Fluid Mechanics and Heat and Mass Transfer, commonly known as CFD - "Computational Fluid Dynamics", has an expressive development in the last 20 years. Initially, as a tool for physical problem analyses in scientific investigations, and nowadays as a powerful tool in solving important problems applied to engineering (Maliska, 1995). CFD permits a detailed investigation of local effects of different types of equipment, such as chemical and electrochemical reactors, heat exchangers, mixing tanks, cyclones, combustion systems, among others.
The departure of hydrogen bubbles which are formed on the cathode surface is strongly influenced by the geometric shape of the electrode (Baber, 1998; Eigeldinger and Vogt, 2000; Janssen, 1981). That is, the more efficient it is the bubble departure the better the mass transfer between the electrode and the electrolytic solution. Thus, the hydrodynamics in electrochemical reactors is generally complicated due to the emission of these gases, posing an extremely ample field for research.

Studies performed earlier show that the over potential of RDH (Hidrogen Evolution Reaction) contributes to up to $10 \%$ of the total operation potential of an industrial cell for the production of sodium-chloride (Andrade, 2000). Its optimization

\footnotetext{
* Author for correspondence
} 
permits electrodes to operate with maximum efficiency, reducing energy consumption. From a technological standpoint, the improvement foreseen attends to the industry of chloride and caustic soda production by electrolyses of sodium chloride, which is the second largest electric energy consumer in the world (Oniciu et alli, 1997). Rapid and rigorous methods of determining speed and concentration profiles improve the understanding of the process, proportioning to the user the possibility of simulating different situations and problems.

In the present work we aimed to numerically analyze the hydrodynamic behavior of the biphase flow (water-hydrogen) in the cathode compartment from a bench scale cell using the computational applicative CFX 4.4 of AEA Technology.

\section{MATERIAL AND METHODS}

\section{Geometry Studied}

The numeric study of the hydrogen bubbles evolution in the cathode compartment, from the electrochemical reactor made available at the Engineering Electrochemical Laboratory of the
Federal University of Campina Grande, state of Paraíba, Brazil is represented. In Fig. 1.

The compartment is constituted by a perforated plate electrode, as shown in Fig. 2, where each one of the orifices is filled with amianthus aiming to impede the formation of hydrogen gas on the internal surfaces, thus allowing the supposition that only the liquid phase crosses through this porous environment. To make the representative geometry of the cathode compartment, according to Fig. 2, some parameters of the electrode were measured: the average diameter of the orifices, $\bar{d}$, the average distance between the edges of the horizontally neighboring orifices, $\bar{x}_{m}$, vertically, $\bar{y}_{m}$, and the average specific area, $\bar{A}_{e}$, by image analysis techniques using the software UTHSCSA ImageTool 2.0. The values obtained are shown in Table 1.

With the geometries parameters defined, a mesh was generated employing the concept of multiblocks, that is, the geometry was divided into several blocks and then a structured mesh was made in each block, resulting in a mesh with 1500.200 control volumes, as it shows Fig. 3.

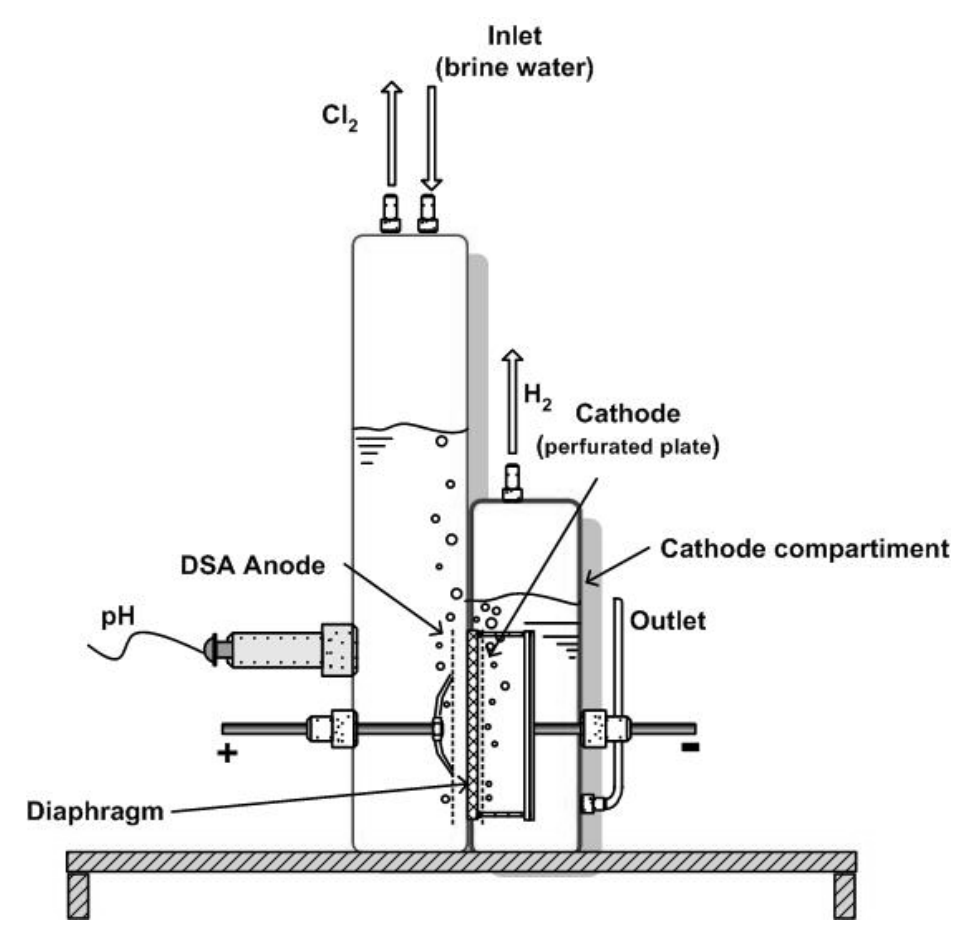

Figure 1 - Sketch of the experimental electrochemical reactor studied 


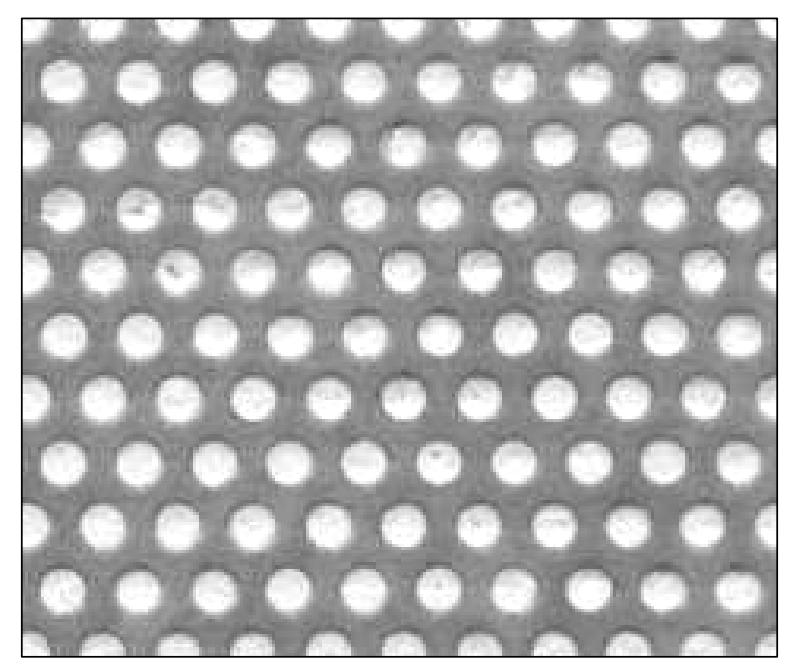

Figure 2 - Mild iron perforated plate electrode.

Table 1 - Dimensions of the electrode from the image analysis.

\begin{tabular}{c|c}
\hline Average dimensions & $\mathbf{m m}$ \\
\hline Diameter, $d$ & 2,50 \\
Horizontal distance, $\bar{x}_{m}$ & 1,53 \\
Vertical distance, $\bar{y}_{m}$ & 4,38 \\
Effective area, $\overline{\mathrm{A}}_{\mathrm{e}}\left(\mathrm{mm}^{2}\right)$ & 3672 \\
\hline
\end{tabular}

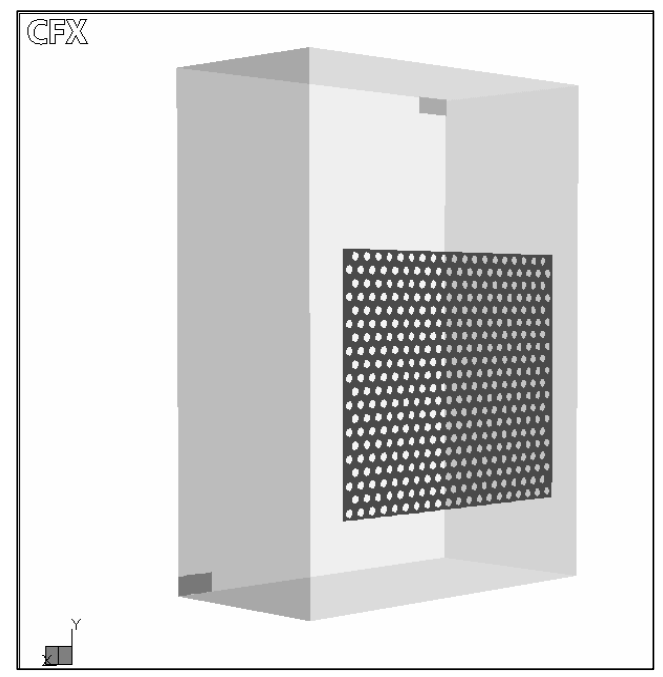

Figure 3 - Cathode compartment to be simulated, tri-dimensional view. 


\section{Modeling of the Problem}

The CFX 4 uses Equations 1 to 3, mass and momentum conservation equations (Navier-Stokes equations), respectively, in a laminar regime.

$$
\begin{gathered}
\frac{\partial \rho}{\partial t}+\nabla \cdot(\rho U)=0 \\
\frac{\partial(\rho U)}{\partial t}+\nabla \cdot(\rho U \otimes U-\mu \nabla U)= \\
=B-\nabla p^{\prime}+\nabla \cdot\left[\mu(\nabla U)^{\bar{T}}\right]
\end{gathered}
$$

Were

$$
p^{\prime}=p+\left(\frac{2}{3} \mu-\zeta\right) \nabla \cdot U
$$

Here $\rho$ is the fluid density, $U=(u, v, w)$ fluid velocity, $p$ is the pressure, $t$ is time, $B$ is a body force, $\mu$ is molecular viscosity, $\zeta$ is a bulk viscosity.

MUSIG assumes that all the particle velocities can be related to the average value algebraically so that it is only necessary to solve one set of momentum equations for all the particles. Essentially we were reducing the multiphase approach to a two-fluid approach with one velocity field for the continuous phase and one for dispersed phase. The continuity equations of particle size groups are conserved and solved to represented the size distribution (Lo, 2000; AEA Technology, 2000). Thus, the equation of continuity for the disperse phase can be written as:

$$
\frac{\partial}{\partial t}(\alpha \rho)+\nabla \cdot(\alpha \rho U)+\frac{\partial}{\partial r}(\alpha \rho \dot{r})=0
$$

Where $t$ is time, $\rho$ is the density, $\alpha$ is the volume faction of the disperse phase, $U$ is the velocity, $r$ is particle size (radius), and $\dot{r}$ is the rate at which the particle changes its size.

"Populational balance is a well-established method for computing the size distribution of the dispersed phase and accounting for breakage and coalescence effects" (AEA Technology, 2000), and can be represented by:

\footnotetext{
* The force of a body can de assessed in several ways. They are: force of impulse, rotational force, resistance force, and magnetic camp force.
}

$$
\frac{\partial}{\partial t} n_{i}+\nabla \cdot\left(u n_{i}\right)=B_{B}-D_{B}+B_{C}-D_{C}
$$

Where $n_{i}$ is the bubble number density, $B_{B}$ and $B_{C}$ are birth rate of group i due to break-up and coalescence respectively, and $D_{B}$ and $D_{C}$ correspond to the death rate.

The rate of total coalescence is given:

$$
Q_{i j}=\left(\theta_{i j}^{T}+\theta_{i j}^{B}+\theta_{i j}^{L S}\right) \eta_{i j}
$$

Where $\theta_{i j}{ }^{T}$ represents turbulent collision rate; $\theta_{i j}{ }^{B}$ is buoyancy force; $\theta_{i j}{ }^{L S}$ is the laminar shear and $\eta_{i j}$ the collision efficiency.

\section{Contour Condition}

The mathematical model used required the implementation of boundary conditions, that is, the walls, entrance and exit of the fluids. The velocity components on the internal walls were considered null, or:

$$
u_{x}=u_{y}=u_{z}=0
$$

In the exit section it was assumed that the derivative of the velocity components in relation to position was null. Fluid entered the cathode compartment through the electrode, with values based on experimental data in the following way: (i) the water was introduced by the velocity component perpendicular to the electrode through the porous environment, filling the orifices at $1.04410^{-3} \mathrm{~m} / \mathrm{s}$. (ii) the gas, $\mathrm{H}_{2}$, penetrated by injection from all of the specific surface of the electrode by the velocity component perpendicular to this surface at 1,984 $10^{-4} \mathrm{~m} / \mathrm{s}$. The other velocity components for the gas and liquid were considered null.

\section{Parameters Used}

In the present study, a bi-phase system containing water (continued phase) and hydrogen (disperse phase) was adopted, with constant physicalchemical properties obtained at $50^{\circ} \mathrm{C}$ as illustrated in Table 2, without the application of electric field, in a laminar, stationary, isothermal regime and with the injection of gas for the generation of $\mathrm{H}_{2}$ bubbles. 


\section{Discretisation}

The equations of the mathematical model were displayed directly in the CFX 4 by the finite volume method and used transfer algorithms in inter-phase ("Inter Phase Transfer"), adopting IPSA for the solution of the mass fraction equations and IPSAC for the solution of momentum equations. To accelerate the convergence of these algorithms for the multiphase model, the SINCE was applied. Finally, the PISO was utilized to the pressurevelocity coupling.

Table 2 - Parameters.

\begin{tabular}{ccc}
\hline Parameters & $\mathbf{H}_{2}$ & $\mathbf{H}_{\mathbf{2}} \mathbf{O}$ \\
\hline $\mathrm{T}(\mathrm{K})$ & 323 & 323 \\
$\rho\left(\mathrm{kg} / \mathrm{m}^{3}\right)$ & 0.07547 & 987.538 \\
$\mu(\mathrm{kg} / \mathrm{m} . \mathrm{s})$ & $9.38310^{-6}$ & $5.72710^{-4}$ \\
$\mathrm{Q}\left(\mathrm{m}^{3} / \mathrm{s}\right)$ & $7.40010^{-7}$ & $2.00010^{-6}$ \\
$\mathrm{~F}(\mathrm{~kg} / \mathrm{s})$ & $5.58410^{-8}$ & $1.97510^{-3}$ \\
\hline
\end{tabular}

$\mathrm{T}$ is the temperature, $\rho$ is the fluid density, $\mu$ is the fluid viscosity, $\mathrm{Q}$ is the volumetric flow and $\mathrm{F}$ the mass flow.

\section{RESULTS AND DISCUSSIONS}

The results presented here were obtained by the CFX 4.4 computational applicative installed in a computer with a Pentium $\mathrm{IV}$ with a $1.7 \mathrm{GHz}$ processor and an "of-board" motherboard, Asus $\mathrm{P} 4 \mathrm{~T}$ - E and 1 GByte of physical memory of Rambus type, using a mesh with 150.200 volumes of control.

\section{Hydrodynamic Analysis}

The analysis of the hydrodynamic behavior in the cathode cell was performed considering different bi-dimensional plans $(x y, y z, z x)$, divided in the cathode compartment with the objective of aiding the analysis of the bi-phase flow in its interior, as shown Fig. 4.

Figs. 5 and 6 illustrate the vectors normalized in the xy plan in the $\mathrm{z}$ position to $0.005 \mathrm{~m}$. In Fig. 5, the vector showed that the liquid phase had a descending behavior. However, it was expected that the gaseous phase would have influenced its behavior, which could be related to a possible inadequacy of the model utilized, or still, by the low velocities of both phases. The velocity vectors in the gaseous phase were distributed in different directions and presented more intensified values of velocities in the proximities of the entrance ${ }^{\dagger}$ region

\footnotetext{
${ }^{\dagger}$ The gas is injected in the cell through the surface of the electrode.
}

of the gas. It was verified that most gas vectors tended to emerge, while others signalized a disposition of being dragged by the liquid phase in the direction of the base exit cell. Based on this analysis, it was possible to observe that the hydrodynamic behavior of the liquid phase wasn't influenced by the gaseous phase behavior. This could be related to a possible inadequacy in some terms of the model or due to the low entrance velocity of the fluids.

\section{MUSIG Model of Five Groups with Coalescence}

According to Olmos et alli (2001), the frequency of coalescence and rupture of the bubbles are essentially determined by the rate of energy of turbulent dissipation and by the diameter of the bubble. Based on this information, the effect of coalescence on the hydrodynamic behavior was analyzed, by means of the model of five groups (MUSIG), (Table 3), along with method k- $\varepsilon$ for the liquid phase and laminar regime for the gaseous phase ${ }^{\ddagger}$.

The influence of the disperse phase over the turbulence of the liquid phase was taken into consideration by the additional Sato term $\left(C_{\mu b}=\right.$ $0.6)$. The $\mathrm{k}-\varepsilon$ model was implemented with the

\footnotetext{
$\$$ The fact of adopting the $\mathrm{k}-\varepsilon$ model for the liquid phase and laminar for the disperse phase is in agreement with the works of Olmos et alli (2001) and Pfleger et alli (1999), as well as with AEA Technology (2000).
} 
constant standards $\left(C_{1 \varepsilon}=1.44, C_{2 \varepsilon}=1.92, C_{\mu}=\right.$ $\left.0.09, \sigma_{k}=1.0, \sigma_{\varepsilon}=1.3\right)$.

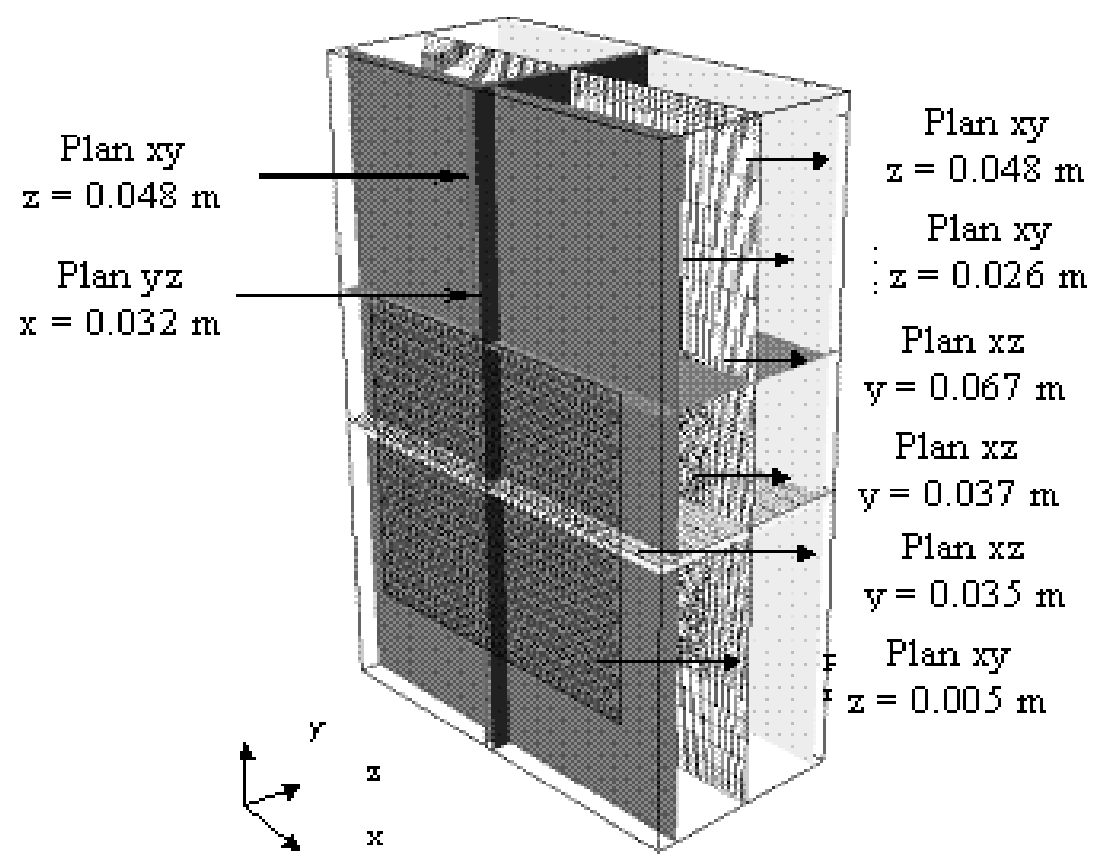

Figure 4 - Geometry with differents plants in $\mathrm{x}, \mathrm{y}$, and $\mathrm{z}$ directions (bi-dimentional)

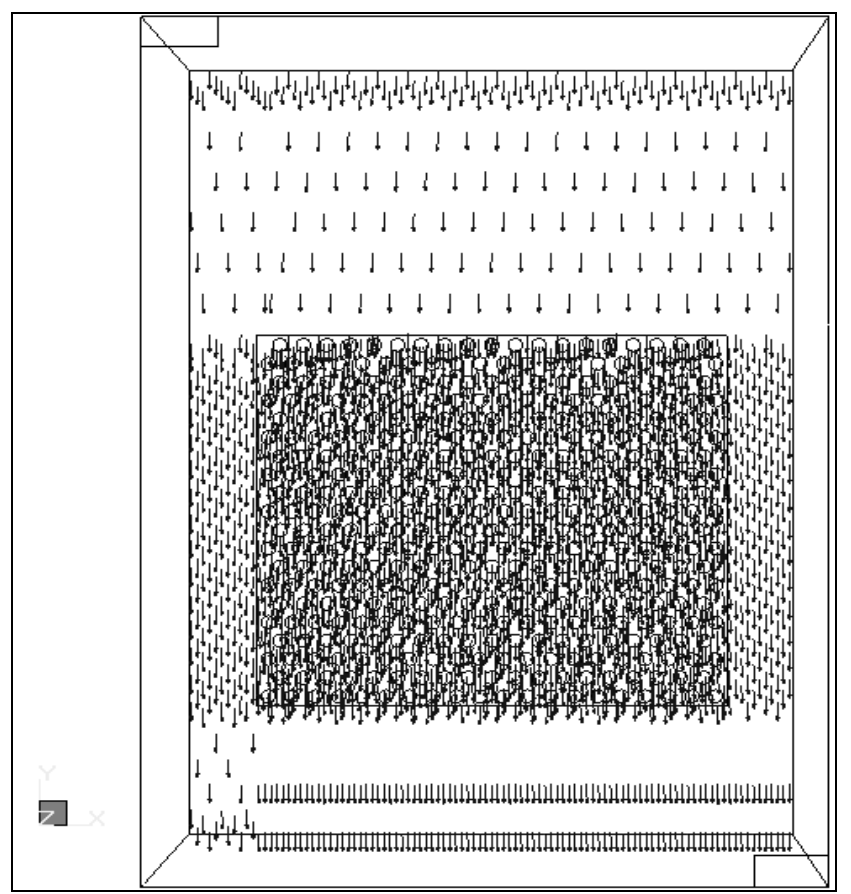

Figure 5 - Vectors representing the continual phase, in plan $x y$ to $z=0.005 \mathrm{~m}$. 


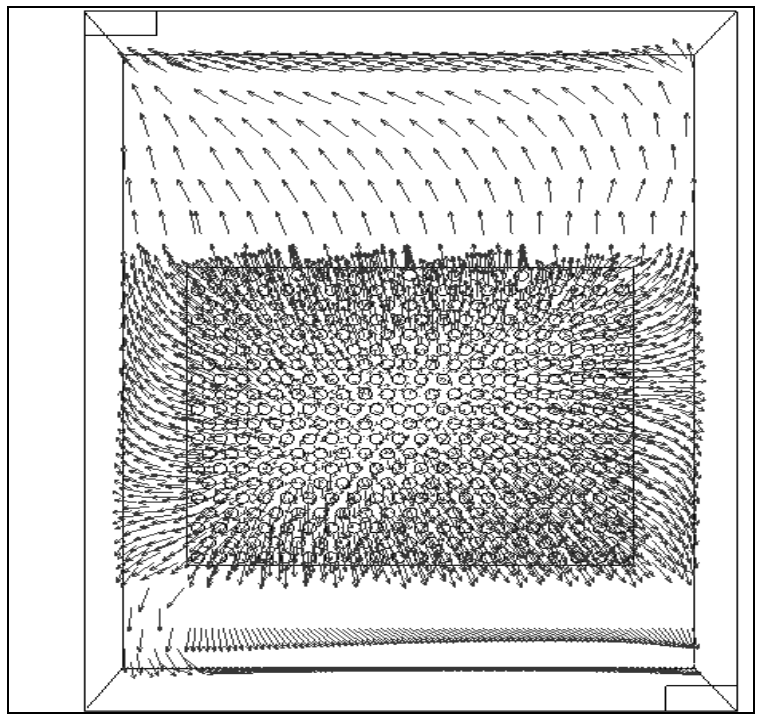

Figure 6 - Vectors for the hydrogen phase. In plan $x y$ to $z=0.005 \mathrm{~m}$.

Table 3 - The diameters distribution to the 5 groups of bubbles.

\begin{tabular}{cccc}
\hline $\mathbf{N}^{\circ}$ of groups & $\mathbf{D}_{\text {initial }}(\mathbf{m})$ & $\mathbf{D}_{\text {end }}(\mathbf{m})$ & $\mathbf{D}_{\text {average }}(\mathbf{m})$ \\
\hline 1 & $1,00 \times 10^{-04}$ & $1,80 \times 10^{-04}$ & $1,51 \times 10^{-04}$ \\
2 & $1,80 \times 10^{-04}$ & $2,60 \times 10^{-04}$ & $2,27 \times 10^{-04}$ \\
3 & $2,60 \times 10^{-04}$ & $3,40 \times 10^{-04}$ & $3,05 \times 10^{-04}$ \\
4 & $3,40 \times 10^{-04}$ & $4,20 \times 10^{-04}$ & $3,84 \times 10^{-04}$ \\
5 & $4,20 \times 10^{-04}$ & $5,00 \times 10^{-04}$ & $4,63 \times 10^{-04}$ \\
\hline
\end{tabular}

As shown in Fig. 7, it was possible to verify that there were fields with intense values, which suggested an influence on the impulse force over the compartment in these regions, on the predominance of the drag force on the rest of the compartment. Another hypothesis was that this intensity was due to the coalescence of the bubbles, in other words, it was possible that in fields where the velocity values were more accentuated, the joining of two or more bubbles could be occurring, causing an increase in their diameter and consequently, due to forces which acted on these bubbles, increasing the velocity of ascension of this gas.

The behavior of the gas in the cathode region is illustrated in Fig. 8 and Fig. 9. It was possible to observe the formation of a gas curtain near the electrode, similar to the one observed experimentally in the bench scale cell.

It was noted that the velocity fields was more intensified in the upper location of the electrode compartment, which could be due the coalescence of the bubbles, and consequently, resulting in the velocity values. The formation of a layer of gas which flowed toward the top of the cells in the proximities of electrode surface with different fields of velocities was observed. These results showed that the development of bubbles coalescent phenomena during the gas injection in the cell could change the velocity field along the electrode by micro-convection.

The Figs. 10 and 11 shows the liquid phase behavior entering in the cathode compartment. Gaseous phase didn't influence the behavior of the liquid phase as identified in Figs. 5 and 6. These results suggested that a more detailed analysis be performed, without neglecting the effect of the break-up of large bubbles, as was presumed by Cavalcanti (2003). 


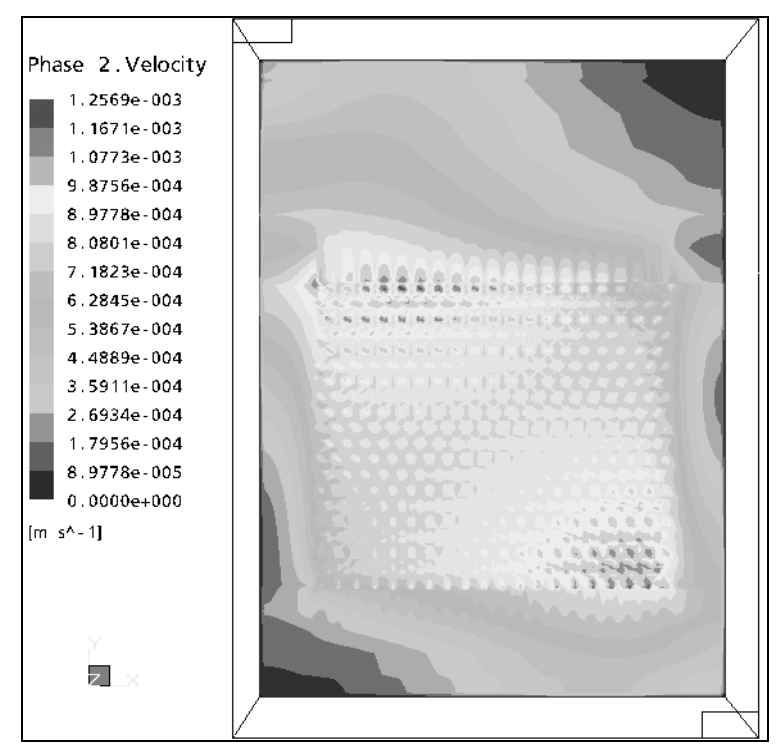

Figure 7 - Representation of the iso-surface of the gas in plan $x y=0.005 \mathrm{~m}$, using the model of coalescence.

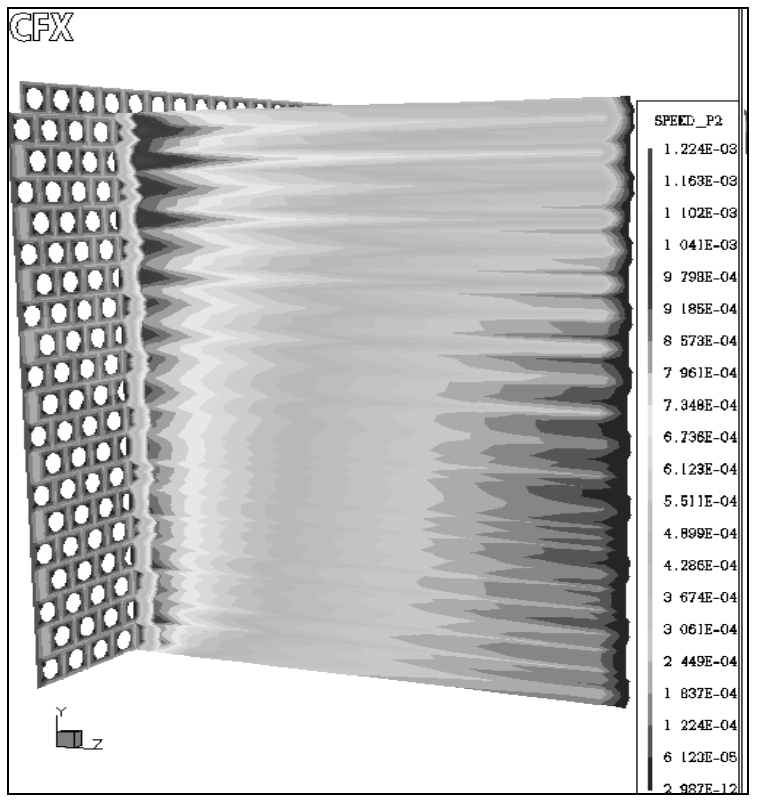

Figure 8 - Representation of the iso-surfaces of gas velocity over a yz plan in center of the electrode surface. 


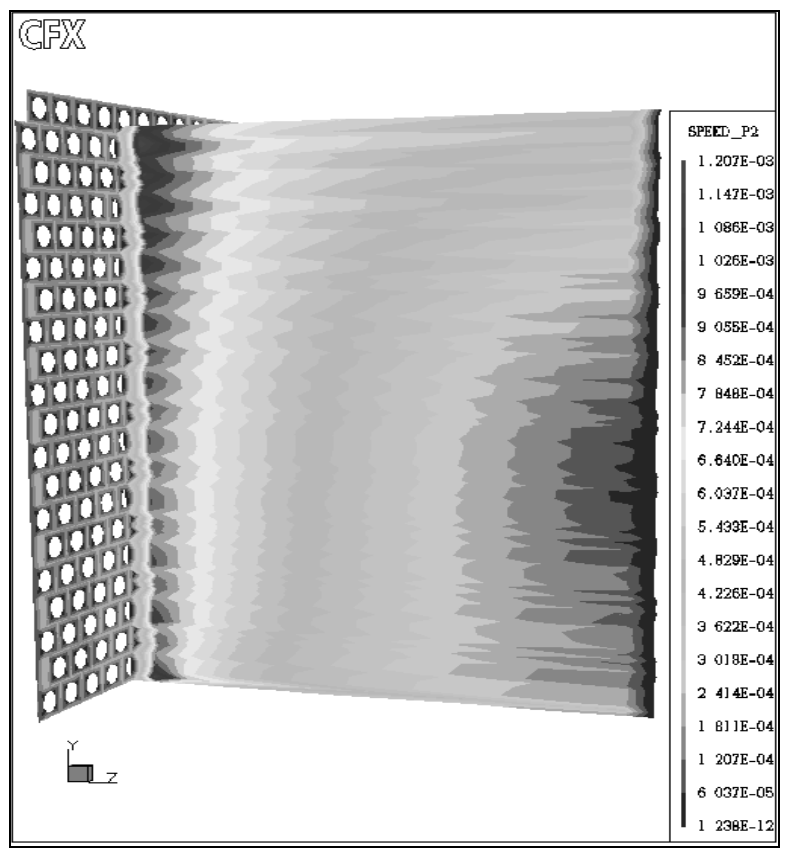

Figure 9 - Representation of the iso-surfaces of gas velocity over a yz plan in center of the orifices.

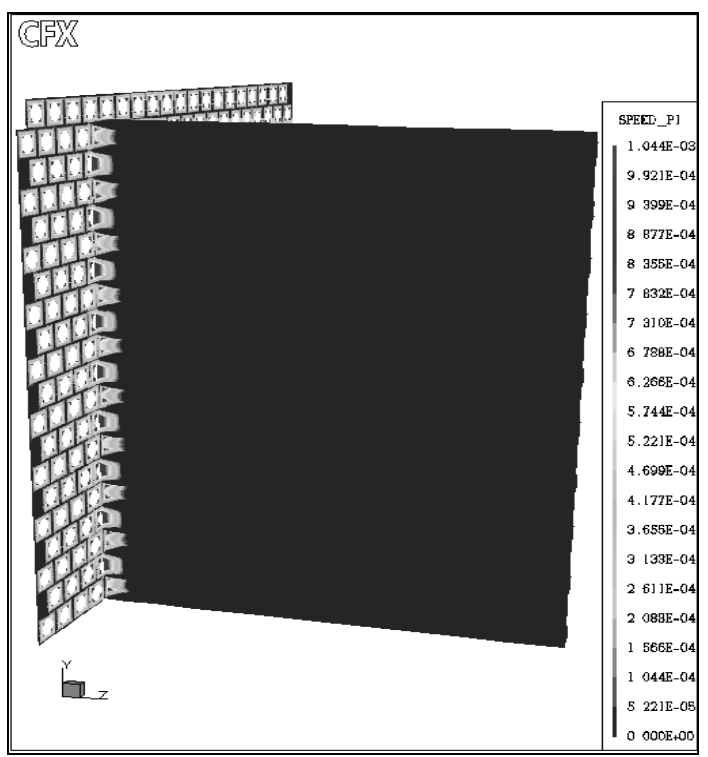

Figure 10 - Representation of the iso-surfaces of the liquid velocity over a yz plan in center of the surface of the electrode. 


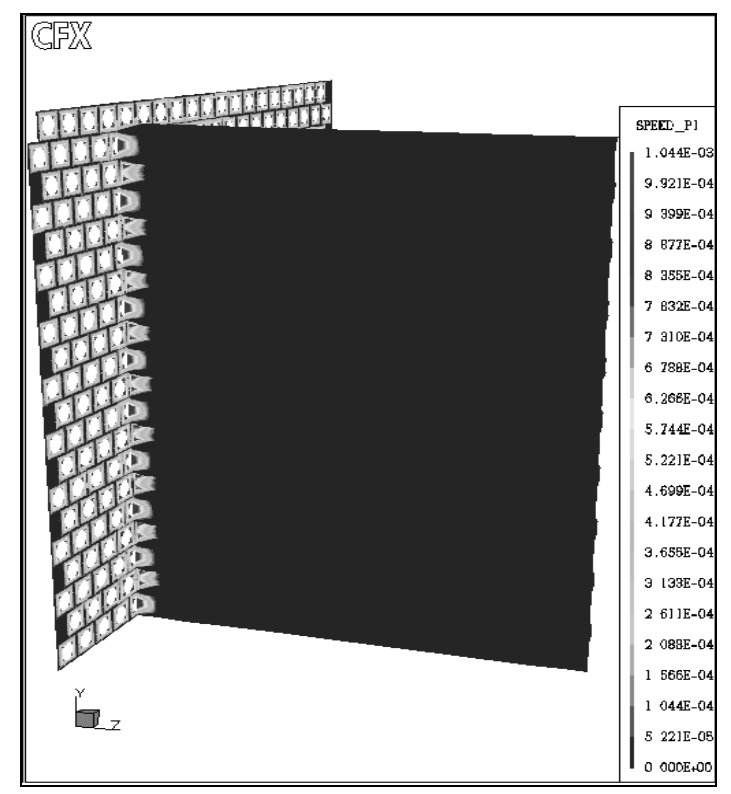

Figure 11 - Representation of the iso-surfaces of the liquid velocity over a yz plan in center of the orifices.

\section{ACKNOWLEDGEMENTS}

The authors thank the Federal University of Campina Grande - Paraiba, for the technical and scientific support, and the $\mathrm{CNPq}$ for the financial support.

\section{RESUMO}

A maioria dos reatores eletroquímicos apresenta reações com crescimento e desprendimento de bolhas de gás influenciando na hidrodinâmica dos reatores e seu estudo é, geralmente, complexo representando um campo amplo para pesquisas. $\mathrm{O}$ presente artigo teve por objetivo estudar um sistema bifásico (gás-líquido) visando prever a influência do desprendimento das bolhas de hidrogênio geradas na superfície específica do eletrodo localizada na semicélula catódica. No entanto, foi idealizado que o gás fora injetado no interior da semicélula através da superfície específica do eletrodo. Com esta hipótese, foi possível estudar e analisar numericamente o comportamento hidrodinâmico das bolhas de hidrogênio no interior do domínio de estudo, aplicando-se os conceitos de fluidodinâmica computacional usando o aplicativo computacional CFX-4 para aplicação do modelo MUSIG ("Multiple-size-group") levando em consideração os fenômenos da coalescência e da distribuição do diâmetro das bolhas.

\section{REFERENCES}

AEA Technology (2000), Manual do usuário para versão do CFX-4.4, AEA Technology plc, Harwell, UK.

Andrade, M. H. S. (2000), Avaliação de Ligas de Níquel como Cátodo para a Reação de Desprendimento de Hidrogênio. Master of Science, Departamento de Química, Universidade Federal de Alagoas, Alagoas, Brazil.

Baber, J., Morin, S. and Conway, B. E. (1998), Specificity of the Kinetics of $\mathrm{H} 2$ Evolution to the Structure of Single-Crystal Pt Surfaces, and the Relation Between opd and upd H. J. of Electroanalytical Chem., 446, 125-138.

Cavalcanti, R. S. (2003), Estudo Fluidodinâmico do Desprendimento de $\mathrm{H}_{2}$ em uma Célula Eletrolítica Utilizando o Aplicativo Computacional CFX. Master of Science, Departamento de Engenharia Química, Universidade Federal de Campina Grande, Campina Grande, Brazil. 
Eigeldinger, J. and Vogt, H. (2000), The Bubble Coverage of Gas-Evolving Electrodes in a Flowing Electrolyte, Electrochimica Acta, 45, 4449-4456.

Janssen, L. J. J. and Van Stralen, S. J. D. (1981), Bubble Behaviour on and Mass Transfer to an OxygenEvolving Transparent Nickel Electrode in Alkaline Solution, Electrochimica Acta, 26, 1011-1022.

Lo, S. (2000), Application of Population Balance to CFD Modelling of Gas-Liquid reactors, Paper submitted to the conference: Trends in Numerical and Physical Modelling for Industrial Multiphase Flows, Corse.

Maliska, C. R. (1995), Transferência de Calor e Mecânica dos Fluidos Computacional - Fundamentos e Coordenadas Generalizadas. Rio de Janeiro : LTC.

Olmos, E.; Gentric, C.; Vial, Ch, Wild, G. and Midoux, N. (2001). Numerical Simulation of Multiphase Flow in Bubble Column Reactors Influence of Bubble Coalescence and Break-up, Chem.ical Engrg. Sci, 56, $6359-6365$.

Oniciu, L.; Agachi, S.; Bugan, J., and Mrekyucaci, A. (1997). Steady State Model of the Electrochemical Process of Brine Electrolysis in DeNora Amalgam Reactor, Hungarian J. of ind. Chem., 25, 2, 81-89.

Pfleger, D.; Gomes, S.; Gilbert, N. and Wagner, H. G. (1999). Hydrodynamic Simulations of Laboratory Scale Bubble Columns Fundamental Studies of the Eulerian-Eulerian Modelling Approach. Chem. Engrg. Sci., 54, 5091-5099.

Received: September 29, 2004; Revised: February 25, 2005 ; Accepted: March 25, 2005. 